\title{
HISTORICAL AND CULTURAL ROOT IN Anil's Ghost
}

\author{
Bimal Kishore Shrivastwa \\ Assistant Lecturer, English Department \\ P.G.Campus Biratnagar, Tribhuwan University, Nepal \\ bimalksrivastav@gmail.com
}

\begin{abstract}
Michael Ondaatje's Anil's Ghost narrates the forgotten history and cultural root of those who were massacred in the mindless violence of Sri Lankan Civil War, particularly the common and downtrodden people. Presenting the central character, Anil, beyond the mainstream culture, political and social scenarios, Ondaatje confirms his affinity to the unprivileged people. The pain agony of war victims is clearly examined through the reconstruction of skeletons. The suppressed and unidentified past comes into existence which is the best way to renovate native history within the literary text. Ondaatje historicizes those people who exist on the margin of canonical history. With this novel, he gives voice to those who were unheard in the official history, records them in art and literature as Sri Lankan artist, Anand reconstructs statue of Buddha.
\end{abstract}

Key Words archeological, genealogy, marginalized, postcolonial, postmodernist, reformation,

A mainstream postcolonial writer, Michael Ondaatje, Sri Lankan born Canadian writer, writes about the historical and cultural facts of Sri Lanka fictionalizing them through literary art. His novel The English Patient, the Booker Prize winner, records the scenario of world war second with a view to recapitulate the distorted history and cultural phenomena. Accordingly, Ondaatje's novel Anil's Ghost is a subtle representation of reformation of history and culture of the marginalized people in Sri Lanka. For that the novel at one level is read as the renovation of the people of Sri Lanka who were not associated in the official history. At another level, it is viewed as the written history and culture of the marginalized people who were brutally killed in the course of Sri Lanka Civil War (1980-90). The novel is "an act of reconstruction of suppressed Sri Lankan culture and history"(Scanlon, 2002).

As Clifford Geertz pointed out, "a cultural is constituted by distinctive set of signifying systems" (Geertz, 1973), all the characters are engaged to reconstruct the life of those missing in the war. Metaphorically, they create the vibrant pictures of Buddha which were destroyed in war, represent the recreation of identity of missing people giving them the voices through the art of words.

In brief author's note Ondaatje explains: "Anil's Ghost is a fictional work set during this political time and historical moments".

Anil Tissera, the protagonist of the novel, is forensic anthropologist, born in Sri Lanka and educated in the west, returns to the country for the first time after fifteen years to investigate "Unknown extrajudicial executions". Ondaatje focuses the historical account of the Civil War in which innocent people were massacred into the mindless violence. Anil is teamed up with a local Sri Lankan archeologist, Sarath Diyasena to complete her mission assigned by International Human Rights Organization. They work together in order to determine whether or not a recent skeleton can provide evidence that the Sri Lankan government has been systematically killing its own people in the campaign of murder. In this context, their investigation begins: "The first body they brought in was very recently dead, the man killed since she had flown in .... she had to stop her hands from trembling".

They search more and more and take four recently buried skeletons to test and identify the cau se of their killing. They bring those skeletons into labs and try to examine them. After that they move in different cities to investigate more skeletons which were buried and were not known to 
the people either they were killed or missed somewhere. Anil aspires to find out the truth of the murder of those innocent people whether by government or not. To prove that mission, she is supported by Sarath.

Anil and Sarath work together to dig out the identity of skeletons, which they find into the archeological sites. They attempt to trace out the cause of the state sponsored murder. When they find a new body buried among the excavations of a sixth-century archeological preserver, Anil's feelings develops with agonies of people and hatefulness towards the government.

The reality of political crisis is clearly presented. We can see Anil narrating the story of past which was undermined by history but alive as the imprint to the mind of Sri Lankan people, which was saved by the art. On the other hand, Palipna, an archeologist in Sri Lankan history is knowledgeable about the context of ancient culture. "Palipna saw his country in fathoms and colors, and Europe simply as a handmass on the end of the peninsula of Asia". This shows that the aura of genuine culture is faded due to the mixture and tiltness towards the western culture. Adopting this aura, the westerners express their superiority upon the eastern countries.

Anil and Sarath find skeletons in Bandarawela states and label the name as tinker, tailor, soldier and sailor. This is an act of identifying missing skeletons. They try to prove whether it is murder or political killing. Anil wants to prove the skeleton as recent one which she found in the course of investigation. This statement gives her search for objective truth: She begins to examine the skeleton again under sulpher light, summarizing the facts of his death so far, the permanent truths, same for Colombo as for try. One free arm broken partial burning, vertebrate damage in the neck. Examination of the poor condition of buried skeleton gives knowledge to continue her investigation through which she traces the identity and culture of missing people.

Anil and Sarath finally investigate Sailor's name and date of abduction. During the course of investigation, they continue it by giving name to each skeletons and date of abduction in which Sailor is the first and foremost skeleton through which they develop the ideas to other skeletons' investigation. Anil feels that by attempting to establish the identity of the skeletons as 'sailor' and find the family to whom it belongs, she will be locating all those who sailor represents: "Who was this skeleton? This representative of all those lost voices. To give him a name would name the rest". In this sense to be nameless is to be without any identity, a lost voice and culture that must be called back into existence. 'Sailor' is representatives of all who cannot name themselves and who rely on others. It shows that names and identities are not fixed entities rather cultural and ideological construction which can be recorded into the span of time.

Anil investigates to create the truth over Sri Lanka. She rushes towards different places with the help of Sarath. During an archeological expedition, Sarath and Palipna encounter cave images of a woman bending over a child. Sarath connects past truth of the mother's mixture of grief and affection for her child with present truth of grief and affection for his homeland. For him "The country existed in a rocking, self-burying motion. Truth, thus, comes finally in to the light. It's in the bones and sediment. It's in character and nuance and mood not in simplicity". Sarath concludes that truth lies in to the skeleton which is the cultural and historical fact.

Palipna treats history and cultural truth as multifaceted artifact. The stone remnants of royal bathing pools and water gardens, the buried cities, the nationalistic fervor he rode and used gave him and those who worked with him, including Sarath, limited her subjects to record and interpret. The things they find as the art can give the root to find out past truth. 
Moreover, Palipna is true interdisciplinarian. As a historian and a scientist, he approaches ruins not with a historical text but with the pragmatic awareness of locally inherited skills.

This shows the relation between history and art. Art is ever-present in history. History strengthens with the touch of art. Palipna's historical evocations give way to Anil and Sarath. Furthermore, Palipna adheres them that history and art are two related parts to record the human instincts. Palipna finds history and culture in different stones, arts and images: Every historical pillar he came to in a field he stood beside and embraced as if it were a person he had known in the past. Most of his life he had found history in stones and carvings.

Consistent with his interdisciplinary approach, Palipna suggests Anil to call Ananda Udgama, an alcoholic gem pit worker who used to be an 'artificer', a ceremonial painter of the sacred ey es on Buddha statues, for help. Palipna explains, "The artificer brings to life sight and truth and presence". Because the artificer is forbidden to look directly in to the eye of the statue and must instead work with a mirror, he is well versed in imagery and the study of souls which would be essential in reconstructing the 'essence' of a human being.

Anil and Sarath go towards the south and hire a minor named Ananda to construct the skeletons head, so that the victim can be identified. They work together to find out the essence of missing skeletons. They want to find out the existence of that skeleton which they named 'sailor' could represent other missing people. Feeling the importance of artist to construct the head and skull of skeleton, they search for Ananda. With great effort, Ananda reconstructs the head for skeleton to make it "identifiable". Anil watches the artician act of Anand keenly. What he produces, however, is not the face of Ruwan Kumara but a younger face from which radiates what both Sarath and Anil recognizes as "a peacefulness he wanted for any victims" . Watching Ananda at work, Anil realizes that he is squatting in a painful way that is bound to produce a permanent mark on the bone. She gets the importance of art and labour to reconstruct the skeleton.

Most of the characters are engaged on reconstructing act of skeleton to identify of victims. They discover the skeletons in different cites and reconstruct them to give essence which show them the way to find out other missing essence.

This asks the reader to engage in the act of reconstruction, piecing together the stories and psychologies as Sri Lankan artist, Ananda, pieces together the ruined Buddha. Like Ananda's reconstruction, the reader's can be imperfect, a human artifact with visible sutures. We can see all his energy goes into creating "composure" we see in his reconstruction of Ruwan Kumara's skull and Buddha's face and head. Ananda continues to be an "artificer". As he climbs the ladder to the Buddha's head, he is wearing of an old shirt of Sarath's with his Sarong, a recognition that "he and the woman Anil would always carry the ghost of Sarath Diyasena". We cannot simply say what is Sarath's ghost, but surely he is partly the ghost of history and that is also the "irony of history" with which his brother associated him. Anyway, the mission of historicizing to historyless people continued and got succeeded.

In metaphoric level, the search of truth and reconstruction of skeletons' skull and head is an attempt to create new history of that land. They find different images and carve in their journey which gives the beginning of new historical thinking. Palipna is the good researcher who can advocate past and present. He was once a leading member of the first generation of Sri Lankan archeologists, who wished to preserve what was left of their cultural heritage. He moves like a romantic historian to fill the imagined whole. "Palipna could move within archeological sites as if they were his own historical homes from past lives- he was able to guess the existence of a 
water garden's location unearth it, reconstruct its blanks, fill it with whites lotus". This becomes the road map for Anil and Sarath to take their mission ahead.

Ondaatje assimilates history through the representation of the different kinds of ideas. It is the past history in which the writer wants to associate his identity. He is in diasporic identity, in which, he himself feels a state of statelessness, and so, he wants to make an outlet through the recuperation of the history which is his objective of searching his identity and culture.

Anil has worked in places that make her acutely aware of the billions of years in which contemporary cosmology calculates the age of earth and universe. One of her "tenderest discoveries" was the "almost four million" year old footsteps of a pig, a hyena, a rhinoceros and a bird at Laetoli in Tanzania". Her tenderness towards the ancient footprints suggests wonder at their accidental preservation. To record the scattered lives, Anil takes the bold step keeping her own life in danger.

Anil, Palipna, Sarath and even Ananda all focus on history, or on forensic anthropology but Gamini the surgeon "has chosen not to deal with the dead. He avoided the southowing corridors, where they brought the torture victims to be identified". The bodies have to be identified to place them in nationality history. Gamini treats to the war victim, "Hundreds of victims had died under Gamini's care. Thousand couldn't walk or use their bowels anymore still. He is a doctor". Gamini knows thousands of political victims who bear to existence in Sri Lankan history rather were slammed into the houses and dark rooms. To identify those political victims and innocent faces, Anil and Sarath ask help with Gamini.

Moreover, a brief look at Sri Lanka's recent history suggests that Ondaatje's unwillingness to take sides or offer solution may owe as much to local conditions as to postmodernist theory. The politics and political violence of Sri Lanka seem to reflect back post-modern notion of the collapse of grand narratives. It also seems as the fragility and impermanence of identity of minority who are not safe from the political violence. Ondaatje also points to a sharp ethnic and cultural split between a largely Hindu, Tamil speaking minority and Buddhist speakers of Sinhala. The Sinhala majority government radicalized the Tamil opposition by declaring Sinhala the nation's only official language. Thus the violence began in that land where many people belong to minority were killed and buried in mass graves without proper rituals.

Ondaatje provides more scenes of political violence which is on going with so many parties to the conflict. It is the violence on property and people which with private quarrels and purposes "Undisciplined police and armed forces carried out murders and robberies while masquerading as guerillas". Violence is widespread that it is often difficult to establish the certainly who the agents of specific killing. In such a condition to identify the victims whose bodies are sometimes grossly mutilated, burned to useless on transported to long distances, is difficult.

Anil looks for permanent truths in the chemical traces that survive in bones. But her competitive protagonist, Sarath insists that truth is inseparable from life. Anil, as forensic experts, analyzes the skeletons' remains to examine the physical characteristics of the victim, together with the cause, manner, time, and place of death with a view to asserting the victims identity. In doing so, they use techniques of pathology, ontology, radiology etc. Anthropological studies may be undertaken to determine the skeleton's death, sex and race.

They also try to find the government enemies list to prevent them from being slaughter. They bring skeletons in to the Colombo city to investigate. But officials immediately separate her from the skeleton, and although she is permitted to report to some and counter-insurgency 
experts in an anti-terrorism unit. In this context, she realizes that without evidence her findings will have no real value. After fifteen years' absence she has finally begun to identify with Sri Lankans. She says, "I think you murdered hundreds of us". She wants to include herself into the minority history equating her with them.

The entire novel is narrated simultaneously to the two layers of audiences. In one level, Ondaatje is unfolding his own story through Anil, and in another level his audiences are the readers. After introducing Anil and her arrival in Sri Lanka, the plot of the novel shifts to another event that the search of skeletons and their reconstruction. Anil knows that "this was the place of a complete crime. Heads separated from bodies. Hands broken off. None of the bodies remains all the statutory had been removed ... . To search the skeletons in such a horrific land, Anil dares knowing that minorities can get the power and voice for their existence.

When Anil disappears form the investigating room, the narrative moves to Gamini, in his office, turning through the black and white photographs of victims that a civil rights organizations brings to him. When he reaches to the third photograph, he recognizes his brother's body by its "innocent wounds", "the scars from a childhood biking accident and a fight with a cricket stump. And though he is a man who has chosen not to deal with the dead, Gamini realizes that he must do so now, that if he does not talk to his brother at this moment, his brother disappear form his life". So he begins a "permanent conversation" with his brother who had always been his rival, but who in death is simply what he is "no longer a counter of argument, no longer an opinion that Gamini refused to accept". The metaphor of the piesta conveys grief and love towards his brother. He saw that "there are many piestas of every kind". This reflects the love and life as the story of Hindu princess, Sabitra.

Ondaatje insists that throughout the account of contemporary reality, old realities must be reconfigured. Global citizens, such as Anil, are new model of human beings. Ondaatje quotes a line form the poet Robert Duncan, "The drama of our time is the coming of all men into one fate". The boundary between history and human body is not fix which is flexible as the changing scenario. This shows that there is not the fix law to bound the people of every century but the history which can assimilate every being of every centuries be recorded in history. They can have different life styles and philosophies which can be their way of life.

Reconstruction of statue of Buddha symbolically refers to the reconstruction of culture of the past. The statue was devastated or destroyed by armed forces and now been reconstructed. Similarly, the history of minority is being reconstructed which was destroyed by the political civil war. When the story ends, it carries out a kind of shape like Ananda's reconstructed statue of Buddha.

As a believer of genealogy, Ondaatje makes the novel a reconstructed history of down trodden people. Thus, the unheard history of the minority people, their culture is recuperated through the medium of art. History created by official people and the history of marginal people has been clearly presented here. Presenting the central character beyond the mainstream political, economical and social scenario Ondaatje confirms his affinity to the down trodden people. It is also an opportunity of Sri Lankan people to know the hidden and suppressed history and their cultural root through the literary artifact.

\section{References}

Greetz, Clifford (1973) "Thick Description: Toward an Interpretative Theory of culture". The Interpretation of Cultures. Cambridge: CUP.

Scanlan, Margret (2002). "Writing Through Terror". Proquest. 